UDK: 2-13:391

Izvorni naučni rad

Dr. sc. Elvira Islamović, vanredni profesor

Univerzitet u Bihaću

Islamski pedagoški fakultet

elviraislamovic@gmail.com

\title{
ODJEĆA I RELIGIJSKI SIMBOLIZAM
}

O sinovi Ademovi, lijepo se obucite kad hoćete molitvu obaviti.

(Kur'an, Al-A'raf, 31)

\section{Sažetak}

Nigdje se nagost ne poima tako problematičnom kao kod covjeka. Socijalna $i$ moralna dimenzija stida i čovjekova nelagodnost u kulturi obavezuju ga da cijeloga života omotava tijelo odjećom, prilagodavajući je ne samo prirodnom, nego $i$ društvenom okruženju. Čovjek je odijevanjem postao društveno biće, prvotno zaśtitom od vremenskih nepogoda, ozljeda, i stida, potom ukrasom $i$ konačno načinom da izrazi vlastitu individualnost $i$ identitet. Odjeća nije samo materijalni konstrukt, ona poprima brojne duhovne, kulturne i socijalne konotacije. Ona pojedinca determinira, diferencira, transformira i pozicionira odražavajući njegovu ličnu i društvenu situaciju. Već stoljećima, odjeća nema prvotnu funkciju da zaštiti čovjeka od vremenskih nepogoda. Odjeća nije samo komad tkanine koji pokriva tijelo već posrednik $i$ oblik simboličke komunikacije između pojedinca $i$ društva. Odjeća je odavno važna tema većine religija. Višestruko udovoljavajuci ljudskim potrebama, odjeća je vidljivi znak religijske pripadnosti i duhovna ekspresija. Simboli su sastavni dio svake religije. Odijelo je vanjski simbol duhovne djelatnosti, vidljiv oblik unutrašnjeg čovjeka.

Ključne riječi: odjeća, religija, tijelo, religijski simbolizam, homo religiosus

\section{Uvod}

Odjeća je u društvu neprestano predmet propitivanja i moralnih dilema, što je dokaz njene važnosti i pozicije u društvu. Bez obzira na to koliko pažnje pridavali onome što odijevamo, odijevanje je važan aspekt ljudskoga života na koji ne možemo biti ravnodušni. Čak i kada nismo 
svjesni važnosti izražavanja vlastitog identiteta odjećom, on svejedno svjedoči o nama i utječe na naš položaj u društvu. Povijesno i kulturološki, odjeća je opterećena mnoštvom moralnih dvojbi, što pokazuje njezinu moć i značaj u društvu. Odjeća i moda kao jezik, odašilju poruke $i$ informacije, čime se očituje raznovrsnost simbolike odijevanja (religiozna, politička, erotska, rodna, klasna i dr.). Govor o odjeći i modi je uvijek govor o određenom prostoru i vremenu koji proizvode značenja. "Drevni Grk i drevni Perzijanac, ili, što se toga tiče, drevni Arabljanin i drevni Egipćanin, oblačili su se u razuđenim tonalitetima duhovnog "dizajna"svoje odjeće, ali ipak međuse korespondentnima. (Odjeća prikazana na statuama starih Grka veoma je "duhovno" korespodentna sa ihrāmima ili obrednom odjećom muškaraca muslimana za vrijeme hodočašća u Mekki). Kao da su ti tonaliteti zračili sličnim ili uveliko korespondentnim duhovnim porukama"(Karić, 2014: 74). Grčka odjeća je bila usklađena s ljudskim likom u njegovoj punini, ljepoti, slobodi i plemenitosti. Ona izražava sklad duha i tijela. U podjeli na krojenu i drapiranu odjeću u antici, povjesničari ističu da je krojena odjeća koja sputava tijelo i onemogućava njegovo slobodno kretanje, za Grke bila barbarska te da je pripadala neslobodnima. Razvojem industrijske civilizacije nestaje magijsko i ritualno obilježje odjevnog predmeta.

\section{Magična odjeća}

Arheološka, antropološka i povijesna istraživanja dokazala su postojanje i oblikovanje različitih dijelova odjeće koja je motivirana mitskim ili religijskim razlozima. Područje religijskog, blisko je povezano s područjem kulture. Religija se odnosi na sferu svetoga, najvišega značenja (Durkheim 1965, Luckman 1967). Kada se religija inkorporira u vladajuće tradicije različitih kolektiviteta, ona dobiva specifična kulturna obilježja koja je s tim kolektivitetom povezuju. Anthony Smith (1986) i Armstrong (1982) smatraju kako kulturni mitovi i simboli imaju moć trajanja koja se reproducira iz naraštaja $u$ naraštaj, unatoč promjenljivim povijesnim i materijalnim uvjetima. Postoje zajedničke niti koje prolaze kroz sve religije: vjerovanje u više biće, vjerovanje kako dobra djela nagrađuju onoga ko ih čini, vjerovanje u život poslije smrti. Ritualno-magijska simbolika odjeće 
jedno je od njenih najkompleksnijih obilježja, nastalo još od najranijih ljudskih zajednica.

Magijska i obredna odjeća starih plemenskih zajednica, potaknuta je čuđenjem spram prirodnih sila poput gromova i munja, poplava i vulkana te misterijima u prirodi koji su ih okruživali. Suočavajući se sa strahom, nerazumijevanjem i nepoznavanjem prirodnih sila i pojava, ljudi su nastojali da se udobrovolje i približe pojavama moćnijim od njih. Imitativnom magijom, prerušavanjem, odgovarajućim izgledom i prinošenjem žrtava, primitivni čovjek je nastojao steći naklonost nadnaravne sile. Novija arheološka i antropološka istraživanja iščezlih civilizacija, obavještavaju o tome da je izvorna svrha odjeće bila magijska. Boja, ornamenti i elementarna odjeća isprva se upotrebljavala da bi se dobre animističke sile privukle, a loše udaljile. "Koliko god oskudna bila, primitivna je odjeća - poput primitivnoga govora gotovo posvuda prepuna magije. Ogrlica od zubi morskog psa ili pojas od kauri školjaka ili perja imaju istu svrhu kao i molitva ili čarolija, te mogu magijski zamijeniti ili češće, dopuniti - čaranje. U prvom je slučaju na djelu jedna vrsta dodirne magije: vjeruje se da zubi morskoga psa onoga ko ih nosi obdaruju kvalitetama okrutna i uspješna ribara. Kauri školjke, s druge strane, djeluju simpatičkom magijom: budući da nalikuju ženskim spolnim organima, smatra se da povećavaju ili čuvaju plodnost.Vjerovanje u nadnaravnu moć odjeće - poput vjerovanja $u$ molitve, uroke i čarolije - ostaje rasprostranjeno i u današnjem civiliziranom društvu, premda ga ocrnjujemo imenom «praznovjerja»"(Lurie2002:182).

Religijski motivi protežu se i na odjeću ljudi antičkog doba iz tzv. epohe politeizma do srednjovjekovne vladarske, svećeničke i redovničke nošnje. U načinu komunikacije s nepoznatim nerijetko su korištene maske, posebni odjevni i drugi predmeti poput talismana, amajlija za koje se vjerovalo da imaju zaštitnu moć od negativnih sila ili da donose sreću. Kao kulturni fenomen i izraz najdubljih religioznih osjećanja, nošenje maski predstavljalo je važan dio svakog religioznog rituala $i$ prikazivanja mitova. Lice je središnji dio čovjekovog identiteta, a promjenom izgleda svoga lica, ljudi su vjerovali da mogu preći granice vlastitog bića, društvenih očekivanja pa čak i ovozemaljskih ograničenja. Asteci su, primjerice vjerovali da $u$ ovakvom transformiranom stanju ljudsko biće postaje božanstvo, jedno 
natprirodno biće ili prikazani mitski heroj. Maske koje prikazuju ljudske ili životinjske skeletne glave se dosta često nalaze na tom području jer je smrt igrala veoma važnu ulogu u religiji meksičkog područja. Kao nezaobilazni predmeti u ritualima i obredima, maske su povezane s religijom i poimanjem svijeta i života drevnih naroda. Maske imaju raznoliku religijsku, društvenu i psihološku funkciju u ritualima koji pružaju zaštitu od nesreće, bolesti ili neprijateljskih sila, ili prizivaju duhove plodnosti. Vjeruje se da štite dobrobiti zajednice, pojedinca i porodice, omogućuju zdravlje i sreću. Maske mogu biti posvećene vjerovanju u božanstvo i pretke ili posvećene duhovima prirode ili izraz lojalnosti prema vladaru, ali i sredstvo manipulacije, opsjene, iluzija ili negiranja autoriteta. Savremene maske, naročito one koje su dio karnevalske scenografije, gotovo u potpunosti su izgubile prvobitne funkcije rekvizita u obredno-religijskoj praksi, preuzevši komercijalne i zabavne funkcije.

Poput maski, i ogrtači su simbol preobrazbi pod djelovanjem ljudskih vještina, i različitih ličnosti koje čovjek može poprimiti. U keltskoj predaji ljudi velikoga istočnog svijeta govore Dagdi: "Onaj koji se ogrne ogrtačem poprima izgled, oblik i lik kakav hoće i zadržava ga dokle god ga ima na sebi" (Rječnik simbola 1994: 450). Kad se redovnik ili monah, navlačeći habit i izričući svoje želje, povlači iz svijeta, on se zagrće ogrtačem ili plaštom. Ta gesta simbolizira povlačenje u sebe i u Boga, korelativno odvajanje od svijeta i njegovih iskušenja, odricanje od materijalnih nagona. Odjenuti halju znači obilježiti izbor mudrosti (ogrtač filozofa). To znači i preuzeti dostojanstvo, funkciju, ulogu koje je ogrtač amblem (ibid.). Ogrtač je, identifikacija i simbol onoga koji ga nosi. Dati svoj ogrtač, znači dati sebe. Kad sveti Martin za siromaha odsijeca polovicu svog ogrtača, to je više od materijalnog dara: gesta simbolizira milost koja pokreće sveca (ibid.). Tako su sofistički učitelji zagrtali svojim ogrtačima svoje učenika dajući im simbolički svoju moć (ibid.).

\section{Odjeća i tijelo homo religiosusa}

Odjeća je odavno važna tema većine religija. U prvobitnom grijehu Adama i Eve o kojem govori židovska, a potom i kršćanska predaja, spominje se pojas od lišća koji prikriva njihov spol, te spoznaja o nagosti i čovjekova potreba da se odjećom zaštiti od pogleda i nelagode. 
Ali Mazrui smatra da postoje teološke teškoće oko prirode istočnoga grijeha i postavlja pitanja: Je li stablo spoznaje ustvari bilo puteno znanje? Da li je prije prvobitnoga grijeha, golotinja bila simbol nedužnosti, a ne osjetilne želje? Postaje li golotinja simbolom osjetilne želje, stida, krivnje, okaljane nedužnosti, tek nakon prvobitnog grijeha? Jesu li Adam i Eva učinili korak prema grešnosti kad su postali svjesni svoje golotinje? (Mazrui 2002:252). U kontekstu židovske i kršćanske predaje koja pominje pojas od lišća kojim se prikriva spol, te upućuje na spoznaju o nagosti, odjeća u ovom slučaju znači izgubljenu nedužnost. "Dolaskom požude u ljudski život, golotinja je prestala biti simbolom nedužnosti i počela stjecati sve konotacije tjelesnog iskušenja. Kad Adam i Eva nisu poslušali Boga, on ih je odjenuo prije nego što ih je isjerao iz vrta. Sam pojam "puti" počeo je podrazumijevati osjetilnost, a sama zamisao da je "tijelo slabo" konotirala je krhkost ljudske snage” (Mazrui 2002: 253).

Islamska tradicija predočena u jednoj poučnoj priči ili hikaji o čovjekovoj odjeći, koju prenosi profesor Fakulteta islamskih nauka u Sarajevu Enes Karić, kazuje o čuđenju praroditelja čovječanstva Adema i Havve različitim animalnim oblicima. "Ademovoj i Havvinoj duši najzačudniji bijaše rep, i to kako mnoge životinje repom pokrivaju svoja stidna mjesta. To zastidi Ademovu i Havvinu dušu, pa njih dvoje usrdno zamoliše Boga da na njima, na ljudima, na tijelu njihovu, ne bude repa, baš nikakva! Ostalo nek Bog stvori što hoće i gdje hoće! Ali, ne i repa! Nipošto! - O ti Ademe, o ti Havvo! Ako nećete repa, hoćete onda odjeću! - reče im Bog strogo. Adem i Havva nikom ponikoše, nastade velika tišina, čule su se unaokolo pjesme rajskih ptica. i Bog, onda, donese svoju odluku, stvori ljudski rod bez repa. Zauzvrat, zapovijedi ljudskom rodu nošenje odjeće, i u duše im usadi klicu stida, a u razum iskru njegovu. I tako nasta stid čovjekov od onog trena kad je Bog stvorio čovjekovo tijelo. I kad god se čovjek stidi, to mu je preostalo od onih davnih pratragova stvaranja” (2014:75).

Ova priča poručuje kako je odjeća postala čovjekova obaveza ali i dar. Autentična islamska duhovnost upućuje, kako u mnoštvu egzistencijalnih darova, koje baštini čovjek-ilovača u carstvu razumne naravi stvorenja, dar ljepote i odjeće kao zaštite, zauzima važno mjesto. “(...) Bog portretira ljepotu i neizrecivu raskoš svoga Lica u Prirodi na jednak način kao i u Objavi. Stranicama Prirode i stranicama Kur' āna 
neprestano je razliježu duhovne jeke jednog istog Stvoritelja. Razlika postoji samo u načinu njegova oglašavanja (...)" (pog. Hafizović u: AlGhazali 1994:117, usp. Hafizović 1996). "Bezuvjetni egzistencijalni vez između Objave i Stvaranja ili između Riječi i Čina, ili između Znanja i Bivanja, ili između Riječi i Prirode, 'Al-Ghazali razotkriva unutar duhovnih perspektiva lijepih Allahovih imena (Esmāullāh'AlHusnā), jer su mu te perspektive otkrile neporecivu skrivenost Kur'āna u Prirodi i cjelovite prirode u Kur'ānu'(ibid.).

Allah Uzvišeni upućuje čovjeka kroz Objavu da se lijepo oblači i vodi brigu o svome izgledu, jer i to spada u domen pokazivanja Allahovih znamenja i darova kojima On obasipa ljude. Islam ne zagovara strogu etiku odricanja, ali propisuje granice i umjerenost.

"Ko je zabranio Allahove ukrase, koje je On za robove Svoje stvorio, i ukusna jela?" Reci: Ona su za vjernike na ovome svijetu, a na onome svijetu su samo za njih. Eto, tako Mi podrobno izlažemo dokaze ljudima koji znaju" (Kur'an, Al-A'raf, 32).

Odjeća muslimana treba da bude čista i lijepa, naročito prilikom obavljanja molitve i susreta sa drugim ljudima. Kur'an objavljuje vjernicima: "O sinovi Ademovi, lijepo se obucite kad hoćete molitvu obaviti!'”(Al-A'raf, 31).

Odjeća višestruko udovoljava ljudskim potrebama. Skriva od pogleda određene dijelove tijela koji po ljudskoj prirodi i osjećaju stida, zahtijevaju pokrivanje. Također, čuva ljudsko tijelo od toplote, hladnoće, neugodnosti i ozljeda. Kur'anski tekst o tome govori:“‘(...) i daje vam odjeću koja vas čuva od vrućine; a daje vam i oklope koji vas u borbi štite; i tako vam upotpunjava blagodat Svoju da biste bili poslušni." (An-Nahl, 81).

Svaka je religija donijela kodeks ponašanja za svoje sljedbenike. Religije sa svojim učenjima i vjerovanjima, značajno utječu na kulturu odijevanja. Odjeća može pokazivati status, stanje ili funkciju koju pojedinac obnaša u religijskoj zajednici, ili vjerski identitet pojedinca. Privrženost religijskim simbolima i pripadnost nekoj vjeri, očituje se u često upotrebljavanim lančićima s križevima, zvijezdama ili drugim simbolima koji se nose oko vrata. U etičkom sistemu većine religija, religiozni čovjek se osamostaljuje i uzdiže iznad vlastitog tijela, oslobađa svoje moći od utjecaja tjelesnih iskušenja te praktično 
povučen u vlastiti duhovni prostor slijedi Božije zakone. Religije usmjeravaju vjernike na ćudoredne norme, vrhovne vrijednosti i stanja unutrašnje produktivne djelatnosti. Stari i Novi zavjet, klasični budizam i islam naglašavaju središnju važnost odricanja od žudnje za bilo kojom vrstom posjeda te od vjernika traže umjerenost i okrenutost pobožnosti.

„O sinovi Ademovi, dali smo vam odjeću koja će pokrivati stidna mjesta vaša, a i raskošna odjela, ali, odjeća čestitosti, to je ono najbolje“" (Kur'an, Al-A'raf, 26). Navedeni kur'anski ajet, sugerira važnost unutrašnje duhovne kakvoće čovjeka, odnosno odjeće bogobojaznostio čemu govori Akbar Eydi: „Obucimo ovu odjeću. Zato, izađimo malo iz zāhirskog (vanjskog) uljepšavanja i uljepšajmo malo i svoj bātin (unutrašnjost)“"(2004:103).

Pozitivne etičke norme, ukorijenjene u etici bivstvovanja, dijeljenja i solidarnosti polaze od središnje postavke da se ljudi moraju osloboditi žudnje i pohlepe za imovinom. Ta temeljna etička pozicija primjenjuje se i na čovjekov odnos prema stvarima, što uključuje i odijevanje. Suzbijanje rasipnosti i lakomnosti, a poticanje štednje, umjerenosti i skromnosti zajedničko je većini religija. Budističko naučavanje slijedeći put spasenja i mudrost savladavanja težnji i strasti tijela, također zagovara etiku odricanja od svijeta. Redovnici ne posjeduju ništa, imaju samo odoru (haljinu žute ili šafranove boje), sandale, brojanicu, iglu, britvu za brijanje glave i brade, cijedilo za vodu (da ne bi nehotice progutali kakvo živo biće) i zdjelicu za milostinju. $\mathrm{Ne}$ ukrašavaju se. ${ }^{1}$ U indijskoj civilizaciji, naučavanje džainizma zagovara strogi asketizam. „Materijalni svijet je zao i čovjek treba težiti da ga se oslobodi.

Zato zagovaraju strogi asketizam, što neki upražnjavaju do odbacivanja nošenja i odjeće. Po tome se, od drugog stoljeća do danas, razlikuju dva smjera: sljedbenici jednog (digambara) su uvijek nagi, a sljedbenici drugog (švetambara) nose bijelu odjeću“(Cvitković 1999:61). ${ }^{2}$

\footnotetext{
1 U budizmu prevladavaju simboli: lopoč, simbol Buddhina rođenja; suncobran, simbol njegovih misionarskih putovanja; kotač, simbol njegova učenja; stablo simbol njegova prosvjetljenja; i otisci stopala, simbol njegovog prisustva u svijetu.

${ }^{2}$ Odbacivanje odjeće, dragocjenosti i uklanjanje kose, znak je odricanja od svakog posjeda. Fundamentalni pojam spasenja je 'beskućništvo'. Ono označava prekid svih
} 
I u židovskoj religiji Talmud od čovjeka traži da njeguje skromnost. U islamu je zabranjena pretjerano raskošna odjeća, zatim odjeća od svile i ona u kojoj ima zlata za muškarce, ali ne i za žene. Protestantska etika isticala je skromnost i jednostavnot odjeće, ograničavanje odjeće na najnužnije, u cilju jačanja svakodnevne askeze. Raskoš i razmetanje smatraju se neprimjernim. Skromnost i asketski duh protestantizma manifestirao se pored ostalog i nošenjem crne odjeće nasuprot crvenoj odori Pape. Kršćani su pozvani slijediti biblijski princip skromnosti pojavljivanjem i oblačenjem na način koji će unaprijediti kršćansko svjedočanstvo te izbjeći ponos, strast i senzualnost. Suprotstavljenost ovosvjetskim žudnjama tijela i negacija tijela postiže se čednom odjećom. U mnogim evropskim gradovima već od 1300. godine, doneseni su zakoni protiv raskoši čije su se odredbe u najvećoj mjeri odnosile na žensku odjeću i nakit. Pred kraj 15. stoljeća, zakoni protiv raskoši zabranjuju primjenu skupocjenih tkanina, bogatih ukrasa te raskošnih oblika. Protivljenja raskoši prvotno su dolazila iz Crkve koja je želju za uljepšavanjem, raskošnim odijevanjem i kićenjem pripisivala prvenstveno ženskom ponašanju i oblicima žudnje koji urušavaju moral. Otkriveno tijelo smatralo se izvorom požude i grijeha. U religioznom htijenju, izbavljenju i napuštanju materijalnoga svijeta, nagona i žudnji, neophodno je podvrgnuti tijelo duhu. U većini religijskih učenja istaknuta je uloga odjeće da simbolički prekriva $\mathrm{i}$ zastire grešnu nagost te predstavlja zaštitu i branu između tijela i okoline. Duhovne vrline, skromnost, čednost i poniznost, potrebno je izraziti kroz odijevanje. Kršćanska inkvizicija vjeruje kako grijeh ulazi kroz kožu te poziva vjernike da pokriju svoje tijelo. Izazivati nečiste misli i želje odijevanjem, znači imati udio u teškom grijehu. U islamu Kur'anski tekst jasno postavlja granice čestitosti u odijevanju shodno cilju zbog kojeg se ono propisuje, čestitost u odijevanju kojom žene, na primjer, skrivaju svoje čari kao štit kojim se brani svekoliki dignitet žena.

„(...)I neka ne dozvole da se od ukrasa njihovih vidi išta osim onoga što je ionako spoljašnje (...)" (An-Nur, 31). Većina islamskih učenjaka smatra da se u spoljašnje ubrajaju bez pretjerivanja lice i dlanovi.

veza sa svijetom, dakle, pre svega, ravnodušnost prema čulnim utiscima i izbjegavanje svakog delanja po svetskim motivima, prestanak 'delanja', nadanja i radnje (M. Veber 1997: 182, u: Cvitković 1999: 63). 
Norme čestitosti u odijevanju koje propisuje Šerijat imaju za cilj zaštitu ženine sigurnosti.

“O Vjerovjesniče, reci ženama svojim, i kćerima svojim, i ženama vjernika neka spuste haljine svoje niza se. Tako će se najlakše prepoznati pa neće napastvovane biti. A Allah prašta i samilostan je" (Kur'an, Al-Ahzab, 59).

Božansko stvaralačko uplitanje u svijet razumne ljudske prirode, put je za uzdizanje ka moralnim vrlinama i udaljavanje od moralnih posrtaja. Zbog toga islam zabranjuje razgolićavanje i preferiranje zavodljivog izgleda, a određenu odjeću i zabranjuje. Nije dozvoljena tijesna odjeća koja pokazuje obrise tijela i prozirna odjeća kroz koju se nazire tijelo. Prozirna odjeća još je jedno sredstvo privlačenja pažnje koje dovodi u pitanje tumačenje čednosti. Ipak, moralnost se još ne zadobija nošenjem pristojne odjeće, već ona izvire iz unutrašnjeg stanja bića (bogobojaznosti). Ova vrsta simboličkog zatvaranja praktično je obezbijeđena odjećom (što je još vidljivije u starijim epohama) čiji je učinak koliko da prikrije tijelo toliko da ga neprestano opominje na red (suknja koja vrši potpuno istu funkciju kao i mantija sveštenika), a da ne mora ništa da propisuje ili izričito zabranjuje (...) (Bourdieu 2001:47).

\section{Duhovne komponente odjeće i korespondentnost poruka koje nosi}

Religijska odjeća sa svojom osobitom simbolikom, vrlo se malo ili nimalo mijenjala kroz stoljeća. Kada neka društvena skupina želi izdvojiti i zaštititi svoju ideologiju, najčešće se koristi određenom odjećom koja označava ono što jesu i u što vjeruju. Simboli su sastavni dio svake religije. Oni podrazumijevaju specifičnu upotrebu riječi, radnji, obreda i odjeće. Vjernik svoj odnos prema nadnaravnom ostvaruje uz pomoć simbola. Simboli integriraju pojedinca u zajednicu. Apstrakcije su nam dosadne pa žudimo za vidljivim znacima. Odijelo je vanjski simbol duhovne djelatnosti, vidljiv oblik unutrašnjeg čovjeka. Pa ipak, simbol može postati tek puki znak koji poništava zbilju, u slučaju kada odjeća postane samo uniforma bez veze s osobnošću. Kad je netko zaređen za svećenika stječe pravo i na nošenje posebne odjeće. Svećenici koji ne pripadaju redovima nose oko vrata kolar (kragnu ili ovratnik bijele boje). Članovi kartuzijanskog reda 
unutar Rimokatoličke crkve nose habit bijele boje i kukuljicu. Franjevci nose redovničko odijelo smeđe boje, poput haljine koja pada do gležnja, a biskup nosi mitru - svečana biskupska kapa pri vođenju obreda ili sudjelovanja u njemu. Kad kardinal okruni novog papu, izgovara sljedeće riječi: „Primi ovu papsku krunu (tijaru) s tri krune i znaj da ona predstavlja Oca prinčeva i kraljeva, Vladaoca svijeta i Vikara našeg spasitelja Isusa Krista. Tri tijare na papisnskoj kruni simboliziraju njegov status kao a) prvosvećenika Rimokatoličke crkve, b) svjetovnog vladaoca, neovisnog u odnosu na bilo kog svjetovnog vladara i c) najvišeg svjetovnog vladaoca“ (Cvitković 1999:158). Odijelo redovnika može imati za cilj da prikrije osobni izgled tijela. Ali uzimanje odijela, u staroj Istočnoj crkvi, kao i u vjerskim redovima može predstavljati pravo drugo krštenje, kojega je učinak tek izvanjski. Kršćanstvo je religija vidljivoga. U kršćanstvu preovlada jedan simbol, a to je križ koji simbolizira mučeničku smrt Kristovu. Njime su ukrašene crkve i svećenička odjeća. Vjernici ga nose u obliku privjeska i tetoviraju po tijelu kako bi time izrazili simbolično pripadnost svojoj religiji. Raspelo djeluje kao nadnaravna sila koncentrirana $u$ predmetima- prema njima se može postupati kao prema upozorenju na grijeh ili kao zaštitnom talismanu. Na čelu pravoslavne Crkve je patrijarh ili arhiepiskop koji na glavi nosi bijelu panakamilovku $\mathrm{s}$ križem na prednjoj strani. Za vrijeme bogoslužja ili čitanja svetih tekstova, Židovi pokrivaju glavu bijelim šalom, šeširom ili kipom (jamulkom), običnom kapicom, i nose talit-šal. Žene pokrivaju glavu, ali nemaju oko vrata šal. ${ }^{3} \mathrm{Za}$ vrijeme obavljanja molitve u islamu, osoba koja predvodi molitvu nosi posebnu odoru (džubu i ahmediju na glavi) koja je namijenjena za tu funkciju. Za vrijeme Hadždža u Mekki, hodočašća kojeg obavljaju muslimani, svi sudionici nose istu odjeću ihram jer se time simbolički iskazuje jednakost pred Bogom. Nakon obavljenog Hadždža vjernik stiče status hadžije i pravo da nosi žutu ahmediju: tanko platno oko kape koje je šarene boje; kod imama i hafiza je bijele boje, kod derviša zelene, crvene ili crne boje.

\footnotetext{
${ }^{3}$ Jarmulke (jidiš), kapica kojom pripadnici židovske religije pokrivaju glavu tokom nekih obreda. Nazivaju je i kipa. Talit, bijeli šal s crvenim prugama, ukrašen resama na četiri kuta kojeg vjernici nose za jutarnje molitve. Nose ga samo punoljetni muškarci (Cvitković 1999: 145).
} 
Za budističke redovnike koji nose odoru - haljinu žute ili šafranove boje, odjeća je također duhovna ekspresija i vidljivi znak religijske pripadnosti. Ono podsjeća na odvojenost od svijeta, na prašinu i odjeću slučajno pokupljenu na putu. „Današnja naklonost svećenikā i časnikā prema laičkoj i građanskoj odjeći umjesto halje i odore bez sumnje se može objasniti razvojem društva; ali u toj pojavi obesvećenja valja vidjeti i gubitak smisla za simbol. Ako odijelo više ne izražava neki odnos simboličke naravi prema unutrašnjoj osobnosti, svećeničkoj ili vojničkoj, zaista je bolje lišiti ga se i uključiti se u opću običnost. Odijelo svjedoči o pripadnosti nekom karakterističnom društvu: svećenstvu, vojsci, mornarici, upravi, itd. Skinuti ga, znači na neki način zanijekati to pripadništvo" (Rječnik simbola 1994: 446-447). Ako dakle odjeća svjedoči o funkciji ili statusu, znači da je ona ponekad njihov simbol, pa čak pridonosi odvajanju jednog ili drugog. ,Sufijski učitelj daje svoj ogrtač onome koga prima u svoju zajednicu. Židovska svećenička odjeća evocirala je makro-mikro kosmičke odnose, a rese na njoj kišu milosti. Češće se upotrebljava hijeratska odjeća, i zamijećeno je da se taj hijeratizam u muslimanskim zemljama proširivao i na građansku odjeću. Hijeratska je odjeća u prvom redu hodočasnička odjeća, koja je često bijela, kao primjerice u islāmu, u šiitskom Iranu, te u Japanu, i budističkom i šintoističkom. Bijela boja je simbol čistoće i jednostavnosti. Hodočasnik mora svoju uobičajenu odjeću zamijeniti posebnom koja ga posvećuje. To je svlačenje navlake starog čovjeka i oblačenje novog čovjeka, o čemu govori sveti Pavao, pročišćenje što prethodi prijelazu. Prije pristupa tajnim kineskim udruženjima isto se tako navlači bijela halja. To podsjeća na svadbenu halju iz Evanđelja (Matej, 22, 11-14)i na halju o kojoj se govori u Otkrivenju $(22,14)$ : Blago onima koji «peru svoje halje» tako (...) da mognu ući u grad na vrata! Ali odjeća je - po svetom Pavlu (2, Kor. 5, 3)i duhovno tijelo, tijelo besmrtnosti zadobivene na svršetku vremena. Već u Starom zavjetu odjeća može obilježavati, pokazujući, duboki značaj onoga tko je nosi. Tako u Danijelovoj viziji $(7,9)$ Pravedni koji se pojavljuje na nebeskom prijestolju, odjeven u bijelo, boju mjeseca, označuje Boga. Prorok Izaija $(61,10)$ zahvaljuje svome Bogu koji ga je spasio i opravdao odjenuvši ga u halju pravednosti i zaogrnuvši ga ogrtačem spasenja“(ibid.). Prema tome, odjeća nije vanjski atribut, bez ikakve veze s naravi bića koje ju nosi, dapače, ona izražava njegovu bitnu i temeljnu zbiljnost. Po bijeloj, sjajnoj, blistavoj odjeći odmah se 
mogu prepoznati anđeli (Matej, 28,3; Luka, 24,4). da ga odjenu u odjeću blaženstva (...). Tako zadobija značaj novoga svijeta u koji stupa" (ibid, 448). Kako židovski i kršćanski pisci, na početku kršćanske ere, tvrde da spasenje na stanovit način uvodi čovjeka među nebeska stvorenja, nije čudno što se često susreće slika odjeće kao simbol vječna života obećanog odabranima ili vjernicima. Poput života i priča s moralnim poukama njegova utemeljitelja Isusa Krista, povijest kršćanstva prepuna je paradoksa što se jasno vide u protuslovlju između trijumfalnih osvajanja i skrušenog podsjećanja da se put u raj osigurava patnjom i gubitkom svega (usp. Tyler Hitchcock, Esposito 2004:320).

Kao nagradu vjernicima u islamu, Kur'an opisuje odjeću stanovnika Dženneta (raja) koja predstavlja nagradu: „Jedni će haljine od dibe, kadife i svakojakih skupocjenih materijala oblačiti“" (Al-Kafh, 31). Zatim sljedeći ajeti:,U kojima će se zlatnim narukvicama, biserom ukrašenim, kititi, a haljine će im, u njima, od svile biti“ (Fatir, 33). „U njima će se narukvicama od zlata kititi i u zelena odijela od dibe i kadife oblačiti, na divanima će u njima naslonjeni biti““ (Al-Kehf, 31). Implikacije grijeha na život nakon smrti, očituju se i u kazni propisanoj u pogledu odjeće za stanovnika Džehennema (pakla). U Kur'anu se navodi: „Toga dana ćeš vidjeti grešnike povezane u zajedničke okove, košulje će im od katrana biti, a vatra će im lica njihova obavijati““ (Ibrahim, 49-50). Odjeća dakle, služi kao vanjski atribut, refleksija stanja svijesti i religiozne posvećenosti. Ona može podariti onima što je nose osjećaj pripadnosti, sigurnosti i dostojanstva. Bez obzira na to o kojoj je vrsti odore riječ, staviti na sebe redovničku odjeću znači odustati od prava da se djeluje kao individua. Izvanjski autoriteti određuju činjenje i nečinjenje. Stalno nošenje službene (religijske) odjeće neke ljude može toliko promijeniti da im postaje teško ili nemoguće djelovati izvan nje. S druge strane, skinuti odoru, može biti i olakšanje, a ponekad i znak neslaganja. Magijskom, obrednom, posvećenom, svečanom ili svetom odjećom, dakle bogoljudskom svezom prožetom odjećom tijelo doživljava svoju mijenu i postaje nositeljem svetih znamenja (Galović, 2001:24). Kojoj god svrsi služila, u svijetu vidljivih formi i u svijetu čovjeka, odjeća je svakako, kako navodi Al-Ghazali, jedno od čuda Njegovih stvorevina i jedan vid znamenja Stvoritelja (1994:8). "Pogledaj vrste odjeće prema njezinoj raznolikosti: sve je to plod stvoren u umu i razboru ljudskome (...)" (ibid, 63). 


\section{Literatura:}

1. Bourdieau, Pierre (2001). Vladavina muškaraca. Biblioteka Femina. Podgorica.

2. Cvitković, Ivan (1999). Religije suvremenoga svijeta. FPN. Sarajevo.

3. Chevalier, Jean i Gheerbrant, Alain (1994). Rječnik simbola. NZMH Mladost. Zagreb.

4. Galović, Milan (2011). Moda. Zastiranje i otkrivanje. Naklada Jesenski i Turk. Zagreb.

5. Hafizović, Rešid (1996). O načelima islamske vjere. Bemust. Sarajevo.

6. Islamović, Elvira (2014). Moda i odijevanje kao sredstvo identifikacije i socijalizacije. u: Zbornik radova (ur.) Irfan Hošić /Međunarodni naučni skup Pažnja! Odjeća, umjetnost, identitet. 7. i 8. oktobar 2013. Tehnički fakultet Univerziteta u Bihaću/Odsjek za tekstilni dizajn.

7. Islamović, Elvira/Ćoralić, Zrinka (2016). Odijevanje i moda u društvu i jeziku. Udružennje „Solidarnost“ Bihać.

8. Karić, Enes (2014 ), Odjeća kao poruka. Bilten. Glasilo Medžlisa islamske zajednice Zagreb. Broj 157. (73-75).

9. Kur'an. (1992). Preveo Besim Korkut.

10. Lurie, Alison (2002). Odjeća kao znakovni sustav. u:Mirna CvitanČernelić et al. (ur.), Moda. Povijest, sociologija i teorija mode. Školska knjiga. Zagreb.

11. Mazrui, Ali (2002). Halje pobune: spol, odjeća i politika u Africi. Moda. Povijest, sociologija i teorija mode. u: Mirna Cvitan-Černelić et al. (ur.), Moda. Povijest, sociologija i teorija mode. Školska knjiga. Zagreb.

12. Tyler Hitchcock, Susan i Esposito, John L.(2004). Religije. Gdje Bog boravi, kamo hodočasnici putuju. National Geographic. Egmont. Zagreb. 


\section{Elvira Islamovic, $\mathbf{P h D}$ \\ University of Bihac \\ Pedagogical Faculty \\ elviraislamovic@gmail.com}

Original scientific article

\section{CLOTHING AND RELIGOUS SYMBOLISM}

„Children of Adam, dress well when attending the mosques“

(Qur'an, Al-A'raf, 31)

\section{Abstract}

Nowhere does the nakedness become so problematic as in a human. The social and moral dimension of shame and man's cultural embarrassment oblige him to cover his body with clothes throughout his life, adapting it not only to the natural but also to the social environment. Through dressing, man has become a social being. Clothes were initially a protection against weather, injuries, and shame, then became a decoration and finally a way to express his own individuality and identity. Clothing is not only a material construct, it takes on numerous spiritual, cultural and social connotations.

It determines, differentiates, transforms and positions an individual, reflecting his personal and social situation. For centuries, clothing has lost its primary function to protect from weather. Clothing is not just a piece of fabric that covers the body but a mediator and a form of symbolic communication between an individual and a society. Clothing is a long-standing theme of most religions. Versatile to human needs, clothing is a visible sign of religious affiliation and a spiritual expression. Symbols are an integral part of every religion. The outfit is an external symbol of spiritual activity, a visible form of an inner man.

Keywords: clothing, religion, body, religious symbolism, Homo religiosus 


$$
\begin{aligned}
& \text { الأستاذة المسـاعدة ألفيرة إسلاموفيتش } \\
& \text { جامعة بيهاتش } \\
& \text { كلية التربية }
\end{aligned}
$$

\section{اللباس والرمزية الدينية}

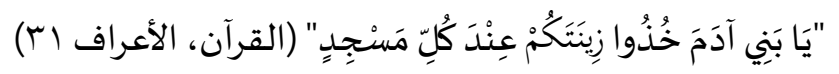

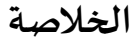

ليس هناك كائن حي يستشكل فياء العري إلى درجة كبيرة كما هو الحال مع الإنسان.

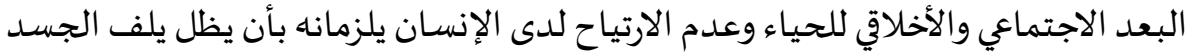
بالملابس طول حياته بهدف تكييف ليس للمحيط الطبيعي فحسب وإنما للمحيط

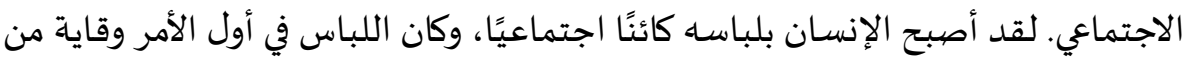
سوء الأحوال الجوية والإصابات وبدافع الحياء، ثم أصبح عبارة عن زينة وأخيراً أصبح نوعًا الإنا

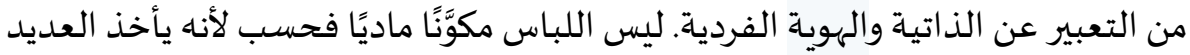
من المدلولات الروحية والثقافية والاجتماعية. اللباس يحدد الفرد ويعرَّفه ويحوَّله ويحدد موقعه، محددًا وضعاه الفردي والاجتماعي. منذ القرون لم يعد دور اللباس وقاية الإنسان

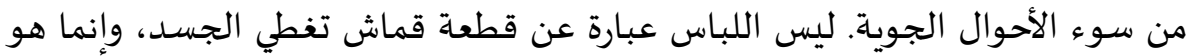

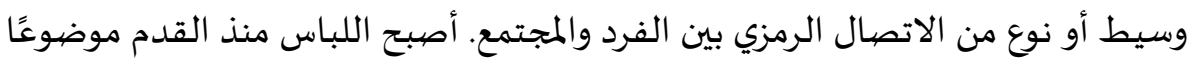

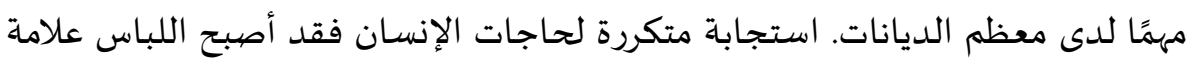

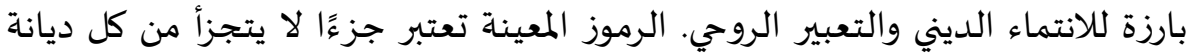
واللباس رمز خارجي للنشاط الروحي وشكل بارز لباطن الإنسان. الكلمات الرئيسة: اللباس، الدين، الجسـد، الرمزية الدينية، الإنسان المتدين 